\title{
Peningkatan hasil belajar sosiologi kompetensi dasar perbedaan dan kesetaraan melalui student teams- achievement division
}

\author{
Herdiwati Herdiwati \\ SMA Muhammadiyah 2 Yogyakarta. Jalan Kapas No.7, Kota Yogyakarta, Daerah Istimewa Yogyakarta 55166, Indonesia \\ herdiwatilukita@gmail.com \\ * corresponding author
}

ARTICLE INFO

Keywords

Hasil belajar sosiologi

Perbedaan dan kesetaraan

Metode STAD

student teams-achievement division

\section{ABSTRACT}

Masih rendahnya prestasi belajar sosiologi diperlukan cara untuk meningkatkannya antara lain dengan melaksanakan Penelitian Tindakan Kelas K D perbedaan dan kesetaraan menggunakan metode student teams-achievement division (STAD). Penelitian Tindakan Kelas dengan metode observasi dan evaluasi dengan tekhnik pengumpulan data menggunakan deskriptif kualitatif dan kuantitatif, di kelas XI IIS3 SMA Muhammadiyah 2 Yogyakarta, tahun pelajaran 2016-2017. Hasil penelitian menunjukkan bahwa proses pembelajaran dengan menggunakan metode student teams-achievement division (STAD) untuk mata pelajaran sosiologi dapat memberi motivasi siswa untuk belajar dengan intensif, karena siswa tertantang untuk berkompetisi dengan siswa yang lainnya baik secara individu maupun secara kelompok dalam keanggotannya. Kuis dalan metode student teams-achievement division (STAD) menyenangkan untuk siswa, karena dengan menggunakan kuis dapat mengukur keberhasilan belajarnya secara langsung, situasi belajar yang menyenangkan akan mempermudah pemahaman. Berdasarkan motivasi dan situasi belajar yang menyenangkan pembelajaran dengan penggunaan metode student teams-achievement division (STAD) dapat meningkatkan hasil belajar siswa. Tingkat ketuntasan pra-siklus $28 \%$, setelah pembelajaran menggunakan metode student teams-achievement division (STAD) dengan dua kali siklus/empat pertemuan, khususnya pada KD perbedaan dan kesetaraan meningkat menjadi $75 \%$.

This is an open access article under the CC-BY-SA license.

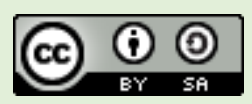

\section{PENDAHULUAN}

Pelajaran sosiologi pada dasarnya adalah pelajaran yang "cukup mudah" untuk siswa dibandingkan dengan pelajaran yang lain yang di UAN-kan di jurusan ilmu-ilmu sosial, seperti matematika, bahasa Indonesia, ekonomi, bahasa inggris maupun geografi. Pada kenyataannya hasil belajar siswa masih belum menggembirakan (Rivaie \& Rustiyarso, 2013), keadaan ini tentunya menjadikan keprihatinan semua pihak terutama guru mata pelajaran sosiologi. Permasalahan masih belum memuaskannya hasil belajar sosiologi merupakan sesuatu yang harus segera dicari pemecahannya.

Salah satu upaya yang akan ditempuh oleh guru untuk meningkatkan hasil belajar siswa adalah dengan cara menggunakan metode Student Team-Achievement Division (STAD), diharapkan siswa akan lebih memahami materi yang diberikan oleh guru yang ditunjukkan dengan hasil belajar 
kognitif, sekaligus dapat menerapkan di dalam kehidupannya di masyarakat, dengan hasil afektif maupun psikomotoriknya. Menurut Dimyati dan Mudjiono (2002) hasil belajar adalah hasil yang dicapai dalam bentuk angka-angka atau skor setelah diberikan tes hasil belajar pada setiap akhir pembelajaran. Nilai yang diperoleh siswa menjadi acuan untuk melihat penguasaan siswa dalam menerima materi pelajaran. Untuk mengetahui tercapai tidaknya tujuan pembelajaran khusus, guru perlu mengadakan tes formatif/ulangan harian pada setiap menyajikan suatu pokok bahasan kepada siswa. Penilaian ini untuk mengetahui sejauh mana siswa telah menguasai tujuan pembelajaran khusus yang ingin dicapai.

Student Team-Achievement Divisions (STAD) ini merupakan salah satu tipe dari model pembelajaran kooperatif dengan menggunakan kelompok-kelompok kecil dengan jumlah anggota tiap kelompok 4-5 orang siswa secara heterogen (Sanjaya, 2008). Diawali dengan penyampaian tujuan pembelajaran, penyampaian materi kegiatan kelompok, kuis dan penghargaan kelompok. Student Team Achievement Divisions (STAD) adalah salah satu tipe pembelajaran kooperatif yang paling sederhana. Siswa ditempatakan dalam tim belajar beranggotakan 4-5 orang yang heterogen. Guru menyajikan pelajaran kemudian siswa bekerja dalam tim, untuk seluruh anggota tim telah menguasai pelajaran tersebut.

Akhirnya seluruh siswa diberikan kuis tentang materi itu dengan catatan, saat kuis mereka tidak boleh saling membantu (Sanjaya, 2008; Slavin, 2015). Langkah-langkah dalam pembelajaran tipe Student Team Achievement Divisions (STAD) adalah sebagai berikut : (1) Guru menjelaskan materi pembelajaran sesuai Kompetensi Dasar yang akan dicapai/Class presentation, (2) Guru memberikan tes/kuis kepada siswa secara individual sehingga akan diperoleh skor awal, (3) Membagi siswa kedalam kelompok-kelompok kecil heterogen dengan kemampuan yang berbeda, jika memungkinkan perbedaan ras, suku bangsa, agama dan gender, yang beranggotakan 4-5 orang/Team Works, (4) Materi yang sudah dipersiapkan didiskusikan dalam kelompok untuk mencapai Kompetensi Dasar, (5) Guru memfasilitasi siswa dalam membuat rangkuman, mengarahkan, dan memberikan penegasan pada materi pembelaajaran yang telah dipelajari, (6) Guru memberikan tes individu, siswa tidak boleh saling membantu menjawab/Individual Improvement Score, (7) Guru memberikan penghargaan pada kelompok berdasarkan perolehan nilai peningkatan ghasil belajar individual dari skor dasar ke skor kuis selanjutnya. prestasi kelompok berdasarkan nilai tes individu/Team Recognation.

\section{METODE}

Rancangan model Penelitian Tindakan Kelas (PTK) ini menggunakan model spiral atau siklus (Ellianawati \& Subali, 2012; Kemmis \& Mc Taggart, 1988; Kristiani \& Prasetyo, 2016; Sanjaya, 2008). Model Penelitian Tindakan Kelas (PTK) ini memiliki empat tahap dari setiap siklus, yaitu: perencanaan, pelaksanaan, observasi, dan refleksi.

Langkah-langkah tindakan kelas direncanakan dalam 2 siklus. Penentuan materi pembelajaran di kelas XI IIS semester 1 yaitu Perbedaan dan kesetaraan. Pada setiap siklus terdiri dari dua kali pertemuan di kelas dengan waktu 2 x 45 menit pada setiap pertemuan, dengan langkah-langkah, sbb:

\section{Perencanaan.}

Kegiatan yang dilakukan dalam perencanaan adalah sebagai berikut: (a) Menyiapkan Rencana Pelaksanaan Pembelajaran sesuai dengan langkah-langkah yang ada dalam metode Student Team Achievement Divisions (STAD) dalam wujud Rencana Pelaksanaan Pembelajaran/RPP, (b) Membuat lembar observasi yang akan digunakan untuk melihat bagaimana kondisi belajar mengajar (di kelas untuk guru dan siswa melaksanakan tugas secara kelompok dengan diskusi dengan metode Student Team Achievement Divisions STAD), (c) Menyusun instrument test/penilaian hasil belajar dalam bentuk: quis, test pilihan ganda biasa dan test uraian.

\section{Pelaksanaan.}

Kegiatan yang dilaksanakan pada tahap ini adalah melaksanakan langkah-langkah pembelajaran yang sudah direncanakan. Pelaksanaan penelitian dibagi 2 siklus: 
Langkah-langkah: (a) Guru memberikan penjelasan tentang kegiatan belajar mengajar yang akan dilaksanakan, (b) Guru menjelaskan materi tentang perbedaan dan kesetaraan, (c) Guru membagi kelompok yang terdiri dari 4 sampai 5 siswasecara heterogen, (d) Guru memberi tugas kepada kelompok untuk dikerjakan oleh anggota-anggota kelompok, (d) Peserta didik yang bisa mengerjakan tugas menjelaskan kepada anggota kelompok lainnya sehingga semua anggota dalam kelompok itu mengerti, (e) Guru memberi kuis/pertanyaan kepada peserta didik, dan pada saat menjawab peserta didik tidak boleh saling membantu, (f) Guru memberi rewards( penghargaan ) kepada kelompok yang memiliki nilai/point tertinggi, (g) Guru melaksanakan evaluasi, (h) Penutup.

\section{Observasi}

Observasi dilaksanakan oleh peneliti dengan kolaborator, dengan berpedoman pada format yang telah disiapkan. Hasil yang diperoleh dari tahap observasi didata kemudian selanjutnya dianalisa. Dari hasil observasi tersebut guru dapat merefleksi diri dengan melihat data observasi. Kegiatan yang sudah dilakukan oleh guru dengan metode Student Team Achievement Divisions (STAD), sudah dapat meningkatkan prestasi siswa atau belum.

\section{Refleksi}

Langkah-langkah: (a) Peneliti menyampaikan kepada kolaborator tentang hal-hal yang sudah direncanakan pada tahap pelaksanaan yang sudah berjalan dengan baik dan yang belum berjalan dengan baik, (b) Siswa diberi kesempatan untuk mengemukakan pendapat tentang apa yang dialami serta kemungkinan usul-usul untuk perbaikan, (c) Kolaborator juga menyampaikan kepada guru maupun siswa apa yang dilihat ketika melakukan pengamatan, (d) Peneliti dan kolaborator bersamasama mengidentifikasi letak keberhasilan dan hambatan dari tindakan yang sudah dilaksanakan pada siklus ke- satu serta menentukan rancangan untuk siklus ke-dua untuk penguatan dan memperbaiki langkah terhadap hambatan/kesulitan yang ditemukan pada pelaksanaan siklus.

Teknik dan Instrumen Pengumpulan Data terdiri dari data kualitatif dan kuantitatif, yaitu:

\section{Data Kualitatif:}

Pertama data tentang situasi belajar mengajar pada saat dilaksanakan Penelitian Tindakan Kelas (PTK) diambil dengan menggunakan lembar observasi guru, yang dilaksanakan oleh kolaborator.

Kedua data tentang tingkat kreatifitas siswa dalam melaksanakan tugas diskusi dengan metode Student Team Achievement Divisions (STAD) dengan menggunakan lembar observasi siswa, yang dilaksanakan oleh kolaborator.

Ketiga data tentang refleksi diri serta situasi yang terjadi di kelas diambil dari catatan kegiatan yang dibuat oleh guru bersama-sama kolaborator.

Keempat data tentang keterkaitan antara perencanaan dengan pelaksanaan diperoleh dari rencana pembelajaran dan lembar observasi, dilaksanakan oleh kolaborator.

\section{Data kuantitatif:}

Berupa data hasil belajar yang diperoleh dengan memberikan tes kepada siswa melalui pretes dan postes dalam pembelajaran dengan metrode Student Team Achievement Divisions (STAD) dilaksanakan. Analisa data/diskripsi dilaksanakan dengan 2 teknik, deskriptif kualitatif dan deskriptif kuantiatatif, yaitu: (a) Teknis analisa data yang digunakan dengan tekhnik deskriptif kualitatif, yakni dengan mendiskripsikan data mengenai pelaksanaan metode Student Team Achievement Divisions (STAD), dari perencanaan, pelaksanaan tindakan, hasil pengamatan dan refleksi dari setiap siklus. Data tentang kualitas pembelajaran juga dideskripsikan secara rinci berdasarkan hasil observasi dengan pedoman observasi yang telah disiapkan untuk guru dan siswa, (b) Teknik analisa data diskriptif kuantitatif didapatkan melalui evaluasi, dalam wujud hasil belajar siswa yang diperoleh dengan tekhnis tes dengan penilaian/penskor-an

Indikator keberhasilan untuk memberikan makna terhadap peningkatan hasil belajar siswa setelah pelaksanaan tindakan digunakan kriteria, yaitu dengan membuat perbandingan antara hasil belajar siswa pada pelaksanaan pretes dengan hasil belajar siswa pada pelaksanaan postes pembelajaran 
dengan metode Student Team Achievement Divisions (STAD), keberhasilan diukur dengan peningkatan hasil nilai rata-rata pencapaian KKM 7, 6, dan minimal 70 \% siswa mencapai KKM.

\section{HASIL DAN PEMBAHASAN}

Memaparkan tentang hasil penelitian dan pembahasannya yang meliputi penerapan metode student teams-achievement division (STAD) Hasil penelitian dan pembahasan pada siklus 1, pertemuan 1 .

\section{Perencanaan}

Dalam perencanaan ini, peneliti menyusun beberapa rencana untuk melaksankan tindakan diantaranya adalah sebagai berikut: (a) Membuat rencana pelaksanaan pembelajaran (RPP), (b) Menyiapkan kuis dengan power point yang diberikan kepada siswa untuk mengetahui pemahaman terhadap materi yang telah dipelajari secara individu,(c) selama mereka bekerja dalam kelompok, Pelaksanaan student teams-achievement division (STAD), (d) Peneliti dalam perencanaan dan pelaksanaan tindakan berkolaborasi dengan guru satu mata pelajaran, yaitu ibu Indri Rosiana Dewi, SSos

\section{Pelaksanaan tindakan}

Dalam tahap perencanaan ini adalah melaksanakan yang telah direncanakan sebelumnya yaitu: Dilaksanakan pada hari Senin, 26 September 2016 pada jam pelajaran ke 3-4, jam 08.30-10.00, dengan pokok bahasan kemajemukan.

\section{Hasil observasi siklus I / pertemuan 1}

Pengamatan yang dilakukan oleh kolaborator yang juga merupakan guru mata pelajaran sosiologi. Kolaborator bertugas mengamati seluruh aktivitas peneliti dan siswa selama proses pembelajaran pada setiap siklus berlangsung. Untuk mempermudah pengamatan yang dilakukakn oleh observer, kegiatan pengamatan berpedoman pada lembar observasi yang dirancang sebelumnya oleh peneliti,

Berdasarkan hasil observasi kolaborator tentang kegiatan guru dan siswa pada proses pembelajaran dapat disimpulkan bahwa kegiatan belajar-mengajar pada siklus I pertemuan ke-1 berlangsung sesuai rencana pelaksanaan pembelajaran. tetapi perlu ada beberapa kegiatan yang perlu diperbaiki terutama perhatian siswa yang baru $60 \%$ siswa yang mengikuti proses pembelajaran dengan baik, sedangkan yang $40 \%$ belum mengikuti dengan baik.

\section{Refleksi siklus I, pertemuan ke-1}

Berdasarkan hasil observasi peneliti dan kolaborator merencanakan dan menentukan langkahlangkah untuk siklus selanjutnya, yaitu: (a) Guru agar lebih memperhatikan kepada beberapa siswa yang kurang fokus pada waktu penjelasan materi ajar, (b) Pelaksanakan diskusi agar berlangsung dengan baik sesuai apa yang seharusnya yaitu saling menjelaskan materi, (c) pelaksanaan kuis untuk dilakukan perubahan pelaksanaannya, karena guru masih menyampaikan dengan lisan tanpa menggunakan media.

Hasil penelitian dan pembahasan pada siklus 1, pertemuan 2 yang dilaksanakan pada hari Sabtu, 1 Oktober 2016 pada jam ke 1-2 jam 07.00-08.30. pokok bahasan keberagaman, sebagai berikut.

\section{Perencanaan}

Peneliti pada tahap perencanaan pada siklus I/pertemuan 2 yang dilakukan adalah: (a) Membuat rencana pelaksanaan pembelajaran (RPP) dengan pokok bahasan perbedaan dan kesetaraan (keberagaman), (b) Menyiapkan kuis dengan power point yang diberikan kepada siswa untuk mengetahui pemahaman terhadap materi yang telah dipelajari secara individu, selama mereka bekerja dalam kelompok. 
Pelaksanaan tindakan

Kegiatan akhir

Guru memberi kuis/pertanyaan tentang keragaman kepada siswa, dan pada saat menjawab siswa tidak boleh saling membantu, Guru memberi reward (penghargaan) kepada kelompok yang memiliki nilai/point tertinggi.

Hasil Observasi siklus I/pertemuan 2 pelaksanaan pembelajaran sudah lebih baik dari pertemuan ke-1, walaupun masih ada $30 \%$ siswa yang masih kurang baik dalam mengikuti pembelajaran sesuai yang dikehendaki oleh peneliti. Keadaan ini ditindaklanjuti oleh peneliti dan kolaborator untuk melakukan perencanaan tindakan selanjutnya dengan lebih lebih strategis lagi pada siklus II. Hasil evaluasi siswa pada kuis siklus I tentang kemajemukan dan keragaman dapat dilihat pada Tabel 1.

Tabel 1. Hasil evaluasi siswa pada kuis siklus I tentang kemajemukan dan keragaman

\begin{tabular}{ccccl}
\hline No & Kelompok & $\sum$ benar & $\sum$ nilai & \multicolumn{1}{c}{ Keterangan } \\
\hline 1. & I & 8 & 80 & Tuntas \\
2. & II & 6 & 60 & belum tuntas \\
3. & III & 7 & 70 & Belum tuntas \\
4. & IV & 8 & 80 & Tuntas \\
5. & V & 7 & 70 & belum tuntas \\
6. & VI & 8 & 80 & Tuntas \\
7. & VII & 6 & 60 & belum tuntas \\
8. & VIII & 7 & 70 & Belum untas \\
\hline
\end{tabular}

Berdasarkan Tabel 1 dapat dilihat bahwa siswa yang mengikuti proses pembelajaran masih kurang, karena kuis yang dikerjakan secara kelompok ketuntasannya belum baik. Ketuntasan ratarata yang diperoleh siswa pada kuis I adalah:

Prosentasi nilai rata-rata kuis $=$ Jumlah Skor X $100 \%$

$$
\text { Skor maksimal }
$$

Prosentasi nilai rata-rata kuis $=570=71 \%$

$$
800
$$

Kriteria ketuntasan minimal (KKM) yang ditetapkan adalah 76, maka dapat disimpulkan bahwa baru $71 \%$ dari jumlah siswa yang tuntas, sedangkan sisanya $29 \%$ siswa belum tuntas.

Refleksi siklus I, pertemuan 2

Refleksi dilakukan untuk mengkaji ulang hasil pelaksanaan siklus I, guna menentukan langkah perbaikan pada siklus II. Walaupun terjadi perbaikan pelaksanaan proses pembelajaran baik oleh guru maupun siswa pada siklus I pertemuan yang ke-2, namun ternyata ketuntasan belajar di kelas XI IIS2 kompetensi kemajemukan dan keragaman dengan pembelajaran menggunakan metode student teams-achievement division (STAD) belum seperti yang diharapkan oleh guru karena baru mencapai $71 \%$. Berdasarkan hasil kognitif peneliti berharap siswa dapat menjalankan kehidupan dalam kemajemukan dan keragaman dalam masyarakat Indonesia yang majemuk dan heterogen, dalam kehidupan yang deferential, oleh karena itu peneliti bersama kolaborator merencanakan langkah tindakan selanjutnya pada siklus II. Perencanaan perbaikan dari hasil refleksi yang akan dilakukan pada siklus II, adalah: (a) Langkah student teams-achievement division (STAD) sudah kronologis, materi juga sudah disampaikan guru dengan baik, tetapi perlu lebih sistimatis, (b) Pada proses belajar dikelompok belum semua siswa melaksanakan sesuai yang diharapkan oleh guru, sehingga guru sebaiknya lebih intensif lagi mengawasi kegiatan kelompok pada waktu siswa belajar bersama untuk memahami materi sesuai kompetensi dasar yang ditentukan, (c) Diperlukan untuk membentuk kelompok yang baru agar lebih heterogen, terutama dengan memperhatikan penyebaran tingkat kemampuan kognitif siswa, (d) Pelaksanaan kuis dilakukan perubahan dari siklus I, dengan menggunakan media yang lebih menarik dan mudah dilaksanankan.

Hasil penelitian dan pembahasan yang dilaksanakan pada siklus II/pertemuan 1, terdiri dari: 
Perencanaan

Peneliti pada tahap perencanaan pada siklus II yang dilakukan adalah: (a) Membuat rencana pelaksanaan pembelajaran (RPP) dengan pokok bahasan perbedaan dan kesetaraan, (b) Menyiapkan kuis dengan power point yang akan diberikan kepada siswa untuk mengetahui pemahaman terhadap materi tentang deferensiasi sosial dan stratifikasi sosial yang telah dipelajari secara individu, selama mereka bekerja dalam kelompok, (c) Pelaksanaan student teams-achievement division (STAD), (d) Peneliti dalam perencanaan dan pelaksanaan tindakan berkolaborasi dengan guru satu mata pelajaran, yaitu ibu Indri Rosiana Dewi, SSos, (e) Peneliti pada tahap perencanaan pada siklus II yang dilakukan adalah melaksanakan kegiatan sesuai desain yang telah dibuat sebelumnya. Persiapan dilakukan setelah diskusi dengan kolaborator, berdasarkan hasil evaluasi dan refleksi siklus I. yaitu hasil belajar siswa yang belum memenuhi target yang ditetapkan.

Pelaksanaan tindakan siklus II pertemuan 1

Pelaksanaan tindakan pada siklus II dilaksanakan dalam 2 pertemuan seperti halnya dilakukan pada siklus I yang masing-masing pertemuan dilaksanakan 2 jam pelajaran ( 2 x 45 menit). Siklus II, pertemuan 1 dilaksanakan hari Senin, 3 Oktober 2016 pada jam pelajaran ke 3-4, jam 08.30-10.00

Observasi siklus II / pertemuan 1

Kegiatan belajar-mengajar dilaksanakan lebih baik dari pada siklus I, guru lebih memperhatikan kegiatan siswa dalam pelaksanaan pembelajaran dikelompok. $70 \%$ siswa mengikuti dengan baik sedangkan yang $30 \%$ masih mencapai tahap cukup. Dari prosentase hasil observasi dapat disimpulkan bahwa kegiatan belajar-mengajar pada siklus II pertemuan ke-1 tinggal beberapa siswa yang belum melaksanakan instruksi dari guru dalam kelompoknya

Refleksi

Kolaborator melihat meningkatnya proses kegiatan pembelajaran pada siklus II pertemuan 1 sudah lebih baik dibandingkan dengan siklus I, tindakan yang masih perlu dilakukan oleh peneliti adalah memberi perhatian lebih terhadap beberapa siswa yang masih belum bisa mengikuti proses pembelajaran dengan baik.

Pelaksanaan tindakan siklus II pertemuan 2 tahap yang dilaksanakan seperti pada siklus yang telah dilaksanakan sebelumnya, yaitu:

\section{Perencanaan}

Pada tahap perencanaan pada siklus II, pertemuan 2 yang dilakukan adalah: (a) Membuat rencana pelaksanaan pembelajaran (RPP) dengan pokok bahasan, stratifikasi social, (b) Menyiapkan kuis dengan power point yang diberikan kepada siswa untuk mengetahui pemahaman terhadap materi yang telah dipelajari secara individu, selama mereka bekerja dalam kelompok, (c) Pelaksanaan student teams-achievement division (STAD), (d) Peneliti dalam perencanaan dan pelaksanaan tindakan berkolaborasi dengan guru satu mata pelajaran, yaitu ibu Indri Rosiana Dewi, SSos.

Pelaksanaan.

Pelaksanaan tindakan pada siklus II, pertemuan 2 dilaksanakan hari Sabtu, 8 Oktober 2016 pada jam pelajaran ke 1-2, jam 07.00-08.30, materi tentang stratifikasi sosial.

\section{Observasi siklus II/Pertemuan 2}

Kegiatan belajar-mengajar pada siklus II pertemuan 2 sudah seperti yang diharapkan peneliti, 90 $\%$ siswa melaksanakan instruksi dari guru dalam kelompoknya, dan tinggal $10 \mathrm{~s} \%$ siswa masih melaksanakan dengan cukup saja, sehingga pada waktu pelaksanaan kuis dan mengerjakan soal ulangan berlangsung kondusif dan hasilnya lebih baik dari siklus sebelumnya. Hasil evaluasi kuis kelompok dapat dilihat pada Tabel 2. 
Tabel 2. Hasil evaluasi kuis

\begin{tabular}{ccccc}
\hline No. & Kelompok & $\sum$ benar & $\sum$ nilai & Keterangan \\
\hline 1. & I & 8 & 80 & tuntas \\
2. & II & 6 & 60 & belum tuntas \\
3. & III & 9 & 90 & tuntas \\
4. & IV & 8 & 80 & tuntas \\
5. & V & 7 & 70 & belum tuntas \\
6. & VI & 10 & 100 & tuntas \\
7. & VII & 8 & 80 & tuntas \\
8. & VIII & 8 & 80 & tuntas \\
\hline
\end{tabular}

Presentasi nilai hasil kuis $2=\underline{640} \times 100 \%=80 \%$

$$
800
$$

Nilai rata-rata kuis pada siklus II yang juga merupakan nilai kelompok terjadi peningkatan dari siklus I, jumlah siswa yang tuntas adalah $80 \%$, sedangkan yang belum tuntas masih $20 \%$. Untuk hasil ulangan harian yang merupakan nilai individual dapat dilihat pada Tabel 3. Untuk hasil nilai ulangan harian K.D Perbedaan dan kesetaraan, adalah sebagai berikut.

Tabel 3. Hasil ulangan harian

\begin{tabular}{|c|c|c|c|}
\hline No. & Nama & Nilai & Keterangan \\
\hline 1. & Angger Harry Samudra & 76 & tuntas \\
\hline 2. & Brian Taufiqurrohman & 54 & belum tuntas \\
\hline 3. & Fauzan Aufa Akbar & 88 & Tuntas \\
\hline 4. & Grandis Khosa Nadia & 82 & Tuntas \\
\hline 5. & Hanun Atika Sari & 100 & Tuntas \\
\hline 6. & Izza Ali Razzaaq & 78 & Tuntas \\
\hline 7. & Kevin Haikal Ramadhani & 48 & belum tuntas \\
\hline 8. & Kharisma Aula Ramadhani & 78 & Tuntas \\
\hline 9. & Khofifah Hidayati F & 84 & Tuntas \\
\hline 10. & Lathisa Cikal ANdhira & 86 & Tuntas \\
\hline 11. & Liana Alfrida Kemalasari & 80 & Tuntas \\
\hline 12. & Listanto & 78 & Tuntas \\
\hline 13. & Lya Rachmawati P & 93 & Tuntas \\
\hline 14. & Mohammed Alvan Prncipia H & 78 & Tuntas \\
\hline 15. & Muhammad Cally Pratama & 76 & Tuntas \\
\hline 16. & Muhammad Habib Alfa Robby & 0 & - \\
\hline 17. & Muhammad Mufasa Ramadhan & 45 & belum tuntas \\
\hline 18. & Muhammad Risang Adhi S & 78 & Tuntas \\
\hline 19. & Muhammad Salvian Adhi Wa & 44 & belum tuntas \\
\hline 20. & Mutia Rachmi Annisa & 88 & Tuntas \\
\hline 21. & Naufal Daffa Bramantya & 86 & Tuntas \\
\hline 22. & Novinta Wulandari & 87 & Tuntas \\
\hline 23. & Nur Mahendra Adhi Wardhana & 76 & Tuntas \\
\hline 24. & Patrick Yudha wibowo & 64 & belum tuntas \\
\hline 25. & Prasetyo Bagas Wicaksono & 78 & Tuntas \\
\hline 26. & Putri Dewayanti Nur Santoso & 84 & Tuntas \\
\hline 27. & Putri Rosena Uswatun Khasanah & 78 & Tuntas \\
\hline 28. & Rana Azura Novitasari & 52 & belum tuntas \\
\hline 29. & Risaldi Amrista & 40 & belum tuntas \\
\hline 30. & Samia Saddana & 82 & Tuntas \\
\hline 31. & Shaka Adam Mahadika & 40 & belum tuntas \\
\hline 32. & Shellina Mustika Dewi Tsani & 36 & belum tuntas \\
\hline 33. & Sherina Mutiara Putri & 76 & Tuntas \\
\hline 34. & Tassya Dzulfiana Salsabella & 80 & Tuntas \\
\hline 35. & Tri Rif Qutozakiah & 88 & Tuntas \\
\hline 36. & Yurisdan Angga Abdurrahman & 78 & Tuntas \\
\hline
\end{tabular}

Dari Tabel 3 dapat dilihat jumlah siswa yang tuntas mencapai KKM 76 pada ulangan harian KD perbedaan dan kesetaraan adalah: 
Jumlah siswa tuntas X $100 \%$

Jumlah siswa

$27 \times 100=75 \%$

36

Jumlah siwa yang nilainya mencapai 76 ke atas 27 atau $75 \%$ mencapai kriteria ketuntasan minimal, sedangkan yang kurang belum tuntas 9 siswa atau $25 \%$. Hasil analisa tersebut menjelaskan bahwa dengan menggunakan metode Student teams-achievement division (STAD) dapat meningkatkan hasil belajar siswa pada pembelajaran sosiologi KD perbedaan dan kesetaraan.

\section{Refleksi}

Hasil kegiatan pembelajaran pada siklus II bertambah baik, siswa mengerti strategi apa yang digunakan guru dalam proses pembelajaran sehingga motivasi siswa untuk memahami materi semakin meningkat. Peningkatan penguasaan materi justru mereka rasakan terjadi pada waktu proses pembelajaran sedang berlangsung yaitu pada waktu pelaksanaan kuis, karena siswa langsung dapat melihat benar atau salah mereka menjawab. Siswa bersemangat dan riang mengerjakan kuis, karena disertai kompetisi antar kelompok/individual, dalam situasi bermain.

Dari hasil siklus I dan II pelaksanaan pembelajaran dengan menggunakan metode Student teamsachievement division (STAD) dapat meningkatkan hasil belajar siswa. Hal ini dapat dilihat dari perbandingan hasil pembelajaran dari hasil kuis pada grafik siklus I $71 \%$ siswa tuntas, sedangkan pada kuis di siklus II meningkat menjadi $80 \%$. Keadaan ini dapat dilihat pada Gambar 1 dan Gambar 2.

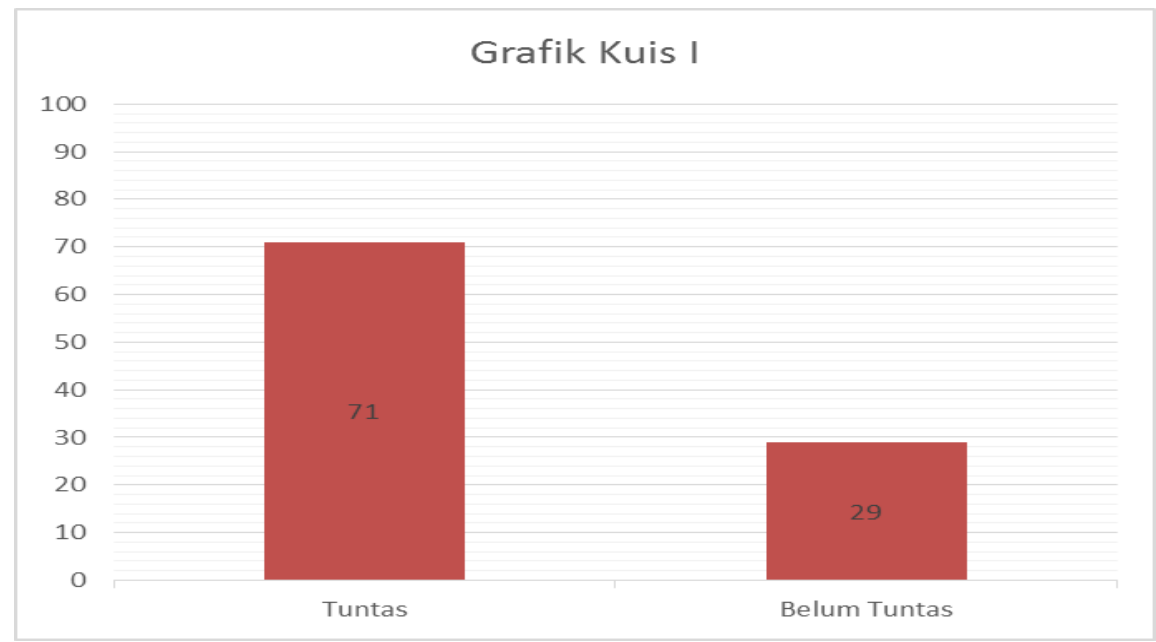

Gambar 1. Grafik Kuis 1

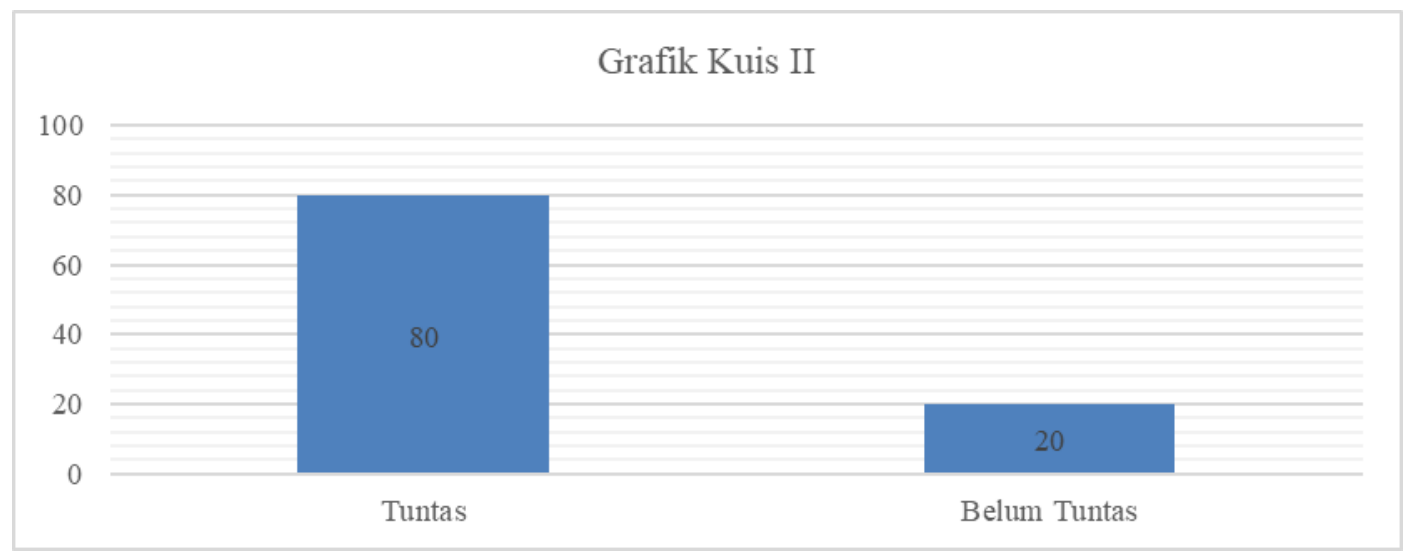

Gambar 2. Grafik kuis 2 


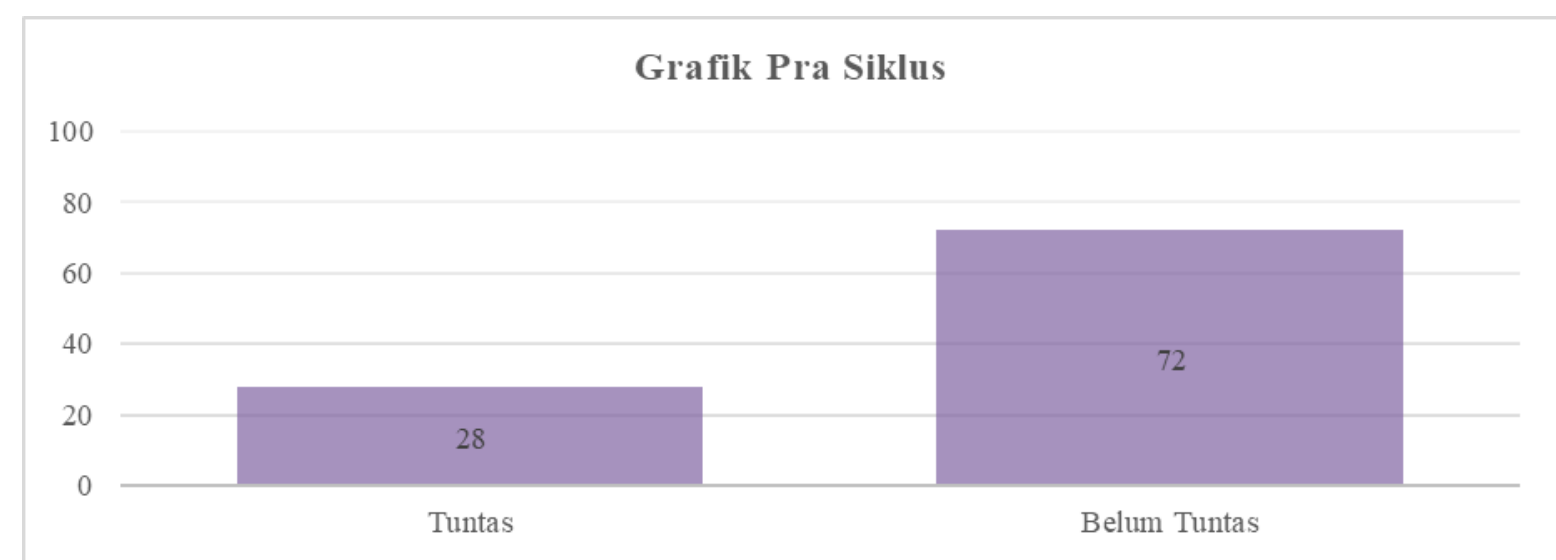

Gambar 3. Grafik hasil belajar pra-siklus

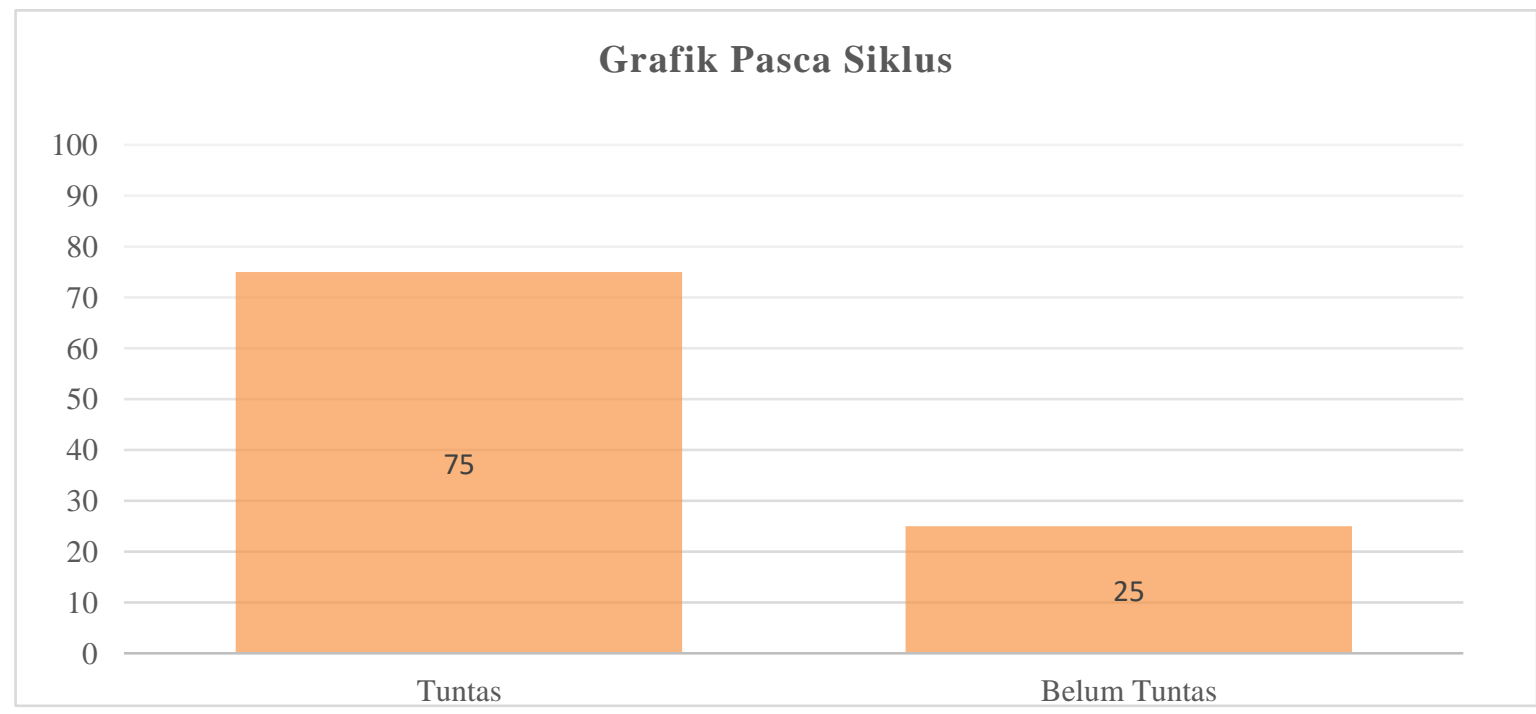

Gambar 4. Hasil belajar pasca siklus

Pada grafik hasil ulangan pra-siklus siswa yang tuntas $28 \%$ dan setelah penggunaan metode student teams-achievement divisiont (STAD) dilaksanakan dua siklus dengan masing-masing siklus 2 pertemuan maka hasil belajar siswa meningkat dengan mencapai ketuntasan $75 \%$. Dalam hal ini target peneliti sudah terpenuhi, karena sudah berhasil mencapai target dengan indikator pencapaian keberhasilan $70 \%$ siswa berhasil tuntas. Peningkatan hasil belajar dapat dilihat dari grafik kuis maupun ulangan harian berikut.

Metode student teams-achievement division (STAD) dapat memotivasi siswa dalam belajar, dan meningkatkan hasil belajar siswa, keadaan ini dapat dilihat pada waktu siswa mempelajari kompetensi dasar perbedaan dan kesetaraan. Peningkatan nilai dari individu dalam kelompok yang terlihat dari hasil kuis, pada siklus I $71 \%$ dan siklus II $80 \%$, dan nilai individu pada hasil ulangan sebelumnya pada kompetensi dasar kelompok sosial siswa yang tuntas baru $28 \%$ (terlampir), sedangkan dengan menggunakan metode student teams-achievement division (STAD) nilai ulangan harian ketuntasannya $75 \%$. Dalam segi afektif siswa memahami dan menyadari dengan baik adanya perbedaan dan kesetaraan sebagai warga negara di negara kesatuan Republik Indonesia yang multikultural. Psikomotoriknya diterapkan dengan teman-teman satu sekolah yang berasal dari berbagai wilayah dan suku bangsa dengan mengedepankan toleransi dan kebersamaan daalam kehidupan sehari-hari.

Metode student teams-achievement division (STAD) akan terus digunakan guru untuk mendukung metode pembelajaran yang lain, tidak hanya di kelas XI IIS 2 tetapi juga di kelas-kelas yang lain, agar siswa menguasai dengan baik materi yang disampaikan. Dengan penguasaan materi yang baik oleh siswa pada setiap kompetensi dasar harapannya akan meningkatkan hasil belajar siswa. 


\section{SIMPULAN}

Berdasarkan uraian dalam hasil penelitian dan pembahasan maka dapat disimpulkan sebagai berikut: (1) Proses pembelajaran dengan menggunakan metode STAD untuk mata pelajaran sosiologi dapat memberi motivasi siswa untuk belajar dengan intensif, karena siswa tertantang untuk berkompetisi dengan siswa yang lainnya baik secara individu maupun secara kelompok dalam keanggotannya. Kuis dalan metode STAD menyenangkan untuk siswa, karena dengan menggunakan kuis dalam mengukur keberhasilan belajarnya secara langsung, belajar dalam situasi yang menyenangkan akan mempermudah pemahaman, (2) Berdasarkan motivasi dan situasi belajar yang menyenangkan dalam pembelajaran, dengan penggunaan metode student teams-achievement division (STAD) dapat meningkatkan hasil belajar siswa, khususnya pada mata pelajaran sosiologi kompetensi dasar perbedaan dan kesetaraan.

\section{REFERENSI}

Dimyati, D., \& Mudjiono, M. (2002). Belajar dan pembelajaran. Rineka Cipta.

Ellianawati, E., \& Subali, B. (2012). Penerapan model praktikum problem solving laboratory sebagai upaya untuk memperbaiki kualitas pelaksanaan praktikum fisika dasar. Jurnal Pendidikan Fisika Indonesia, 6(2). https://doi.org/10.15294/jpfi.v6i2.1119

Kemmis, S., \& Mc Taggart, R. (1988). The action research planner. Deakin University Press.

Kristiani, N., \& Prasetyo, Z. K. (2016). Keefektifan pembelajaran metematika melalui penggunaan media benda konkret pada kelas V SD Timuran. Jurnal Prima Edukasia, 4(2), 163-175. https://doi.org/10.21831/jpe.v4i2.7791

Rivaie, W., \& Rustiyarso, R. (2013). Analisis faktor kesulitan belajar siswa dalam meningkatkan hasil belajar pada mata pelajaran Sosiologi Kelas XII IPS di MA. Syarif Hidayatullah Pontianak. Jurnal Pendidikan Dan Pembelajaran Untan, 2(6).

Sanjaya, W. (2008). Kurikulum dan pembelajaran. Kencana.

Slavin, R. E. (2015). Cooperative learning: Theory, research, and practice. Allyn and Bacon. 